\title{
PENENTUAN BOBOT KEPENTINGAN DECISION MAKER DALAM GROUP DECISION MAKING
}

\author{
Dian Eko Hari Purnomo \\ Pascasarjana Teknik Industri Universitas Gadjah Mada \\ Email: sancoko.45@gmail.com \\ Nur Aini Masruroh \\ Jurusan Teknik Mesin dan Industri Universitas Gadjah Mada \\ Email: aini@ugm.ac.id
}

\begin{abstract}
Generally, there are two criteria which are widely used to determineDM's weight of interest, i.e. competence and consensus. Various studies related to determine DM's weight of interest based on competence or consensus separately have been conducted. Each criterion has its own advantages. The advantage of using competence as a criterion is DMs who have high competence based on their consistence on the decisions made will have high of interest weight. Meanwhile, consensus criterion emphasizes a DM/s contribution to a group without considering the DM's ability or competence. Considering the advantages of both criteria, this study developed a model to determine DM's weight of interestby considering the $D M^{\prime}$ competence and consensus in a GDM. This study used 2 group decision making cases totaling in 6 groups consisting of 5 people each. Collected data was then processed using DM's weight of interest determination method based on competence and consensus. A model was then designed using regression method and fuzzy method. Therefore, a model to determine DM's weight of interest was obtained by considering competence and consensus. DM's weight of interest from each method was then involved in group decision making. The research result showed that group decisions made by involving DM's weight of interest were better decisions. It implies competence and consensus are two criteria which can be used to determine $D M$ 's weight of interest.
\end{abstract}

Keywords: Group Decision Making (GDM); Decision Maker (DM); DM Weights; Competence; Consensus

\begin{abstract}
ABSTRAK
Secara garis besar terdapat dua kriteria yang banyak digunakan dalam menentukan bobot kepentingan DM yaitu kompetensi dan konsensus. Berbagai penelitian terkait penentuan bobot kepentingan DM telah banyak dilakukan baik berdasarkan kompetensi maupun berdasarkan konsensus secara terpisah. Kedua kriteria ini memiliki kelebihan masing-masing.Keunggulan penggunaan kompetensi sebagai kriteria adalah bahwa DM yang mempunyai kompetensi yang tinggi berdasarkan konsistensinya terhadap keputusan yang diambil akan mendapat bobot kepentingan yang tinggi. Sedangkan kriteria konsensus menekankan pada kontribusi seorang DM terhadap grup tanpa memperhatikan kemampuan atau kompetensi dari seorang DM. Dengan mempertimbangkan keunggulan pada kedua kriteria tersebut, maka penelitian ini akan mengembangkan model untuk menentukan bobot kepentingan DM dengan mempertimbangkan kompetensi dan konsesus DM dalam suatu GDM.Penelitian ini menggunakan 2 kasus pengambilan keputusan dalam kelompok dengan jumlah kelompok yang digunakan sebanyak 6 kelompok dan setiap kelompok terdiri atas lima orang.Dari data yang telah terkumpul kemudian diolah dengan menggunakan metode penentuan bobot kepentingan DM berdasarkan kompetensi dan konsensus. Kemudian dilakukan perancangan model menggunakan metode regresi dan metode fuzzy. Dengan demikian diperoleh model penentuan bobot kepentingan DM dengan mempertimbangkan kompetensi dan konsensus. Bobot kepentingan DM yang telah diperoleh masing-masing metode kemudian dilibatkan dalam penentuan keputusan grup. Hasil penelitian menunjukkan bahwa keputusan grup yang diperoleh dengan melibatkan bobot kepentingan DM dengan mempertimbangkan kompetensi dan konsensus menghasilkan keputusan yang lebih baik. Hal ini menunjukkan bahwa
\end{abstract}


kompetensi dan konsensus merupakan dua kriteria yang dapat digunakan untuk penentuan bobot kepentingan DM.

Kata kunci: Group Decision Making (GDM); Decision Maker (DM); Bobot Kepentingan DM; Kompetensi, Konsensus

\section{PENGANTAR}

Penyelesaian masalah GDM dapat dilakukan dengan memberikan bobot kepentingan yang berbeda untuk setiap DM. Bobot yang berbeda untuk setiap DM berpeluang menghasilkan keputusan yang lebih baik. Proses penentuan bobot kepentingan DM mempunyai tingkat kesulitan tersendiri. Kesulitan penentuan bobot kepentingan DM ini telah banyak diselesaikan atau terpecahkan dengan munculnya bermacam-macam metode untuk penentuan bobot kepentingan DM. Beberapa metode penentuan bobot kepentingan DM di antaranya adalah penentuan bobot kepentingan DM yang didasarkan pada kompetensi dari DM (Weiss dan Shanteau, 2003). Metode lain yang dapat digunakan untuk penentuan bobot kepentingan DM adalah metode yang didasarkan pada evaluasi terhadap penilaian DM atas alternatif ditinjau dari konsensus maksimum (Ben-Arieh dan Chen, 2006). Kedua metode ini penentuan bobot kepentingan DM tersebut mempunyai keunggulan masing-masing.

Metode penentuan bobot kepentingan DM berdasarkan kompetensi mempunyai keunggulan tersendiri jika dibandingkan dengan metode penentuan bobot kepentingan DM berdasarkan konsensus. Keunggulan metode ini adalah DM yang mempunyai kompetensi yang tinggi akan mendapat bobot kepentingan yang tinggi. Keunggulan lain yang dimiliki metode ini adalah adanya pengujian konsistensi pendapat dari DM. Semakin konsisten pendapat yang diberikan seorang DM, maka akan semakin tinggi pula bobot kepentingan DM tersebut. Penekanan utama dari metode ini adalah pada kompetensi dari seorang DM berdasarkan konistensi. Padahal kontribusi seorang DM terhadap grup juga perlu diperhatikan dalam pengambilan keputusan secara berkelompok. Kontribusi seorang DM menjadi penting karena dapat mempengaruhi keputusan yang dihasilkan dalam suatu GDM.

Sedangkan metode penentuan bobot kepentingan DM berdasarkan konsensus grup mempunyai keunggulan tersendiri jika dibandingkan dengan metode penentuan bobot kepentingan DM berdasarkan kompetensi. Keunggulan dari metode ini adalah semakin tinggi kontribusi seorang DM terhadap grup maka semakin tinggi pula bobot kepentingan DM tersebut. Pada metode ini yang ditekankan adalah pada kontribusi seorang DM terhadap grup tanpa memperhatinkan kemampuan atau kompetensi dari seorang DM. Padahal kompetensi seorang DM akan berpengaruh kepada bobot kepentingan DM tersebut.

Masalah penentuan bobot kepentingan DM dalam suatu GDM baik berdasarkan kompetensi maupun konsensus memungkinkan terjadinya decision bias. Fenomena decision bias adalah keputusan yang didominasi oleh satu DM, namun belum tentu keputusan tersebut merupakan keputusan yang tepat.Decision bias biasa juga diartikan kesalahan dalam melakukan penentuan bobot kepentingan DM. Kesalahan ini berupa DM yang seharusnya mendapat bobot kepentingan yang tinggi akan tetapi mendapatkan bobot kepentingan yang rendah, begitu pula sebaliknya. Jika terjadi kesalahan dalam penentuan bobot kepentingan DM akan berakibat kepada keputusan grup yang kurang sesuai.

Masing-masing metode penentuan bobot kepentingan DM mempunyai keunggulan dan kelemahan. Penelitian ini akan melakukan perancangan model untuk penentuan bobot kepentingan DM berdasarkan kompetensi dan konsensus. 
Sehingga nantinya akan diperoleh bobot kepentingan DM yang sesuai. Selain itu, dengan adanya model untuk penentuan bobot kepentingan DM berdasarkan kompetensi dan konsensus diharapkan dapat meningkatkan kualitas keputusan yang dihasilkan dari GDM. Berdasarkan uraian sebelumnya dapat diketahui bahwa bobot kepentingan DM adalah variabel yang penting dalam suatu proses pengambilan keputusan secara berkelompok. Selain itu, penentuan bobot kepentingan DM berdasarkan evaluasi atas penilaian DM terhadap alternatif menentukan kualitas dan hasil dari pengambilan keputusan secara keseluruhan.

\section{Penentuan Bobot Kepentingan DM}

Ada beberapa penelitian tentang penentuan bobot kepentingan DM dengan tujuan medapatkan bobot kepentingan DM yang sesuai sehingga diperoleh keputusan grup yang lebih baik, di antaranya memaksimumkan konsensus (Kacprzyk dkk, 1992; Ben-Arieh dan Chen, 2006; Alonso dkk, 2010; Parreiras dkk, 2010). Pada penelitian dengan tujuan memaksimumkan konsensus, para peneliti menggunakan konsep konsensus menurut Ness dan Hoffman (1998) bahwa konsesnsus merupakan keputusan yang telah dicapai ketika sebagian besar anggota grup menyepakati pilihan yang jelas dan hanya beberapa orasng saja yang menentangnya (Ness dan Hoffman, 1998). Selain itu, para DM tidak perlu mengubah opininya, dan untuk meningkatkan konsensus, bobot kepentingan DM diubah sedemikian sehingga DM dengan opini yang sesuai dengan opini grup akan diberi bobot kepentingan yang lebih besar daripada DM dengan opini yang tidak sesuai dengan opini grup. Secara umum, proses pencapaian keputusan grup dengan model ini ditetapkan secara iteratif dengan menggunakan kontribusi DM untuk menyesuaikan bobot kepentingan DM. Keunggulan metode ini adalah bobot kepentingan DM ditentukan secara obyektif berdasarkan penilaian DM terhadap alternatif, bukan penilaian terhadap DM secara langsung.

Tujuan utama dari penelitian ini adalah untuk merancang model penentuan bobot kepentingan DM untuk penyelesaian masalah GDM. Oleh karena itu, objek yang akan digunakan dalam penelitian ini ialah sekelompok anggota yang digabung menjadi suatu grup dan dianggap mampu melakukan suatu pengambilan keputusan, di mana anggota grup tersebut terlibat dalam proses pengambilan keputusan secara berkelompok.

Penelitian pada artikel ini dimulai dengan melakukan perancangan kasus mengenai topik group decision making sehingga diperoleh dua kasus yang digunakan dalam penelitian ini.Pertama adalah kasus penentuan peralatan pada pendaratan darurat. Kedua adalah kasus penentuan tingkat pertumbuhan populasi. Selanjutnya dilakukan proses pengumpulan data berdasarkan dua kasus yang digunakan dalam penelitianini. Proses pengumpulandata menggunakan kuisioner secara online. Maka dari itu, diperoleh data darimasing-masing DM dan masing-masing grup. Data yang telah terkumpul akan diolah menggunakan model Weiss dan Shanteau (2003) untuk mengukur kemampuan atau kompetensi dari DM sedangkan untuk mencapai konsensus maksimum akan mengadopsi model BenArieh dan Chen (2006).

Tahapan selanjutnya setelah data diolah dengan menggunakan metode berdasarkan kompetensi dan konsensus adalah perancangan model penentuan bobot kepentingan DM dengan mempertimbangkan kemampuan atau kompetensi dari DM dan tingkat konsensus dari suatu GDM. Perancangan model dalam penelitian ini akan menggunakan metode regresi dan metode fuzzy. Selanjutnya dilakukan pengujian model yang telah dirancang dengan membandingkan keputusan yang dihasilkan pada penelitian ini dengan kunci jawaban 
atau fakta dari kasus yang digunakan pada penelitian ini.

Model yang dihasilkan dalam penelitian ini merupakan model kombinasi dari dua metode, yaitu metode berdasarkan kompetensi (Weiss dan Shanteau, 2003) dan berdasarkan konsensus (Ben-Arieh dan Chen, 2006). Meskipun pada penelitian ini hanya menggunakan dua kasus untuk pengujian model yang telah dirancang, tetapi pada model yang telah diracang dapat diterapkan untuk kasus lain. Penerapan model hasil rancangan dalam penelitian ini untuk kasus lain mensyartakan data yang digunakan berupa ranking alternatif dan dilakukan lebih dari satu kali pengambilan data pendapat dari masing-masing DM.

\section{HASIL DAN PEMBAHASAN}

Dengan adanya penentuan bobot kepentingan DM yang sesuai dari suatu GDM akan berpeluang menghasilkan keputusan grup yang lebih baik. Keputusan yang lebih baik yang dimaksud dalam penelitian ini adalah keputusan grup yang sesuai dengan pendapat expert, kunci jawaban atau fakta. Pemberian bobot kepentingan DM yang sesuai secara tidak langsung akan berpengaruh kepada keputusan grup.
Penentuan bobot kepentingan DM menjadi penting untuk dapat meningkatkan kualitas keputusan grup.

Penelitian ini menggunakan lima responden dalam setiap grup. Pembentukan grup dalam penelitian ini dilakukan secara acak berdasarkan pengumpulan jawaban responden dari kasus yang digunakan dalam penelitian ini. Pembentukan grup dalam penelitian ini dilakukan tanpa adanya tatap muka antar anggota grup. Pada penelitian ini responden tidak diberikan informasi mengenai pendapat dari responden lain. Tidak adanya informasi mengenai pendapat dari responden lain dengan tujuan untuk menghilangkan pengaruh personal dalam satu GDM. Pengaruh personal yang dimaksud dalam penelitian ini adalah responden yang mempunyai jabatan, pengetahuan yang banyak atau kemampuan akademik yang tinggi dan watak tertentu yang lebih cenderung diikuti responden lain. Selain itu, tidak adanya feedback pendapat dari anggota dalam satu grup bertujuan untuk mendapatkan pendapat yang murni dari responden tanpa adanya pengaruh dari pendapat responden lain. Secara sederhana desain penelitian ini digambarkan seperti pada sebagai berikut:

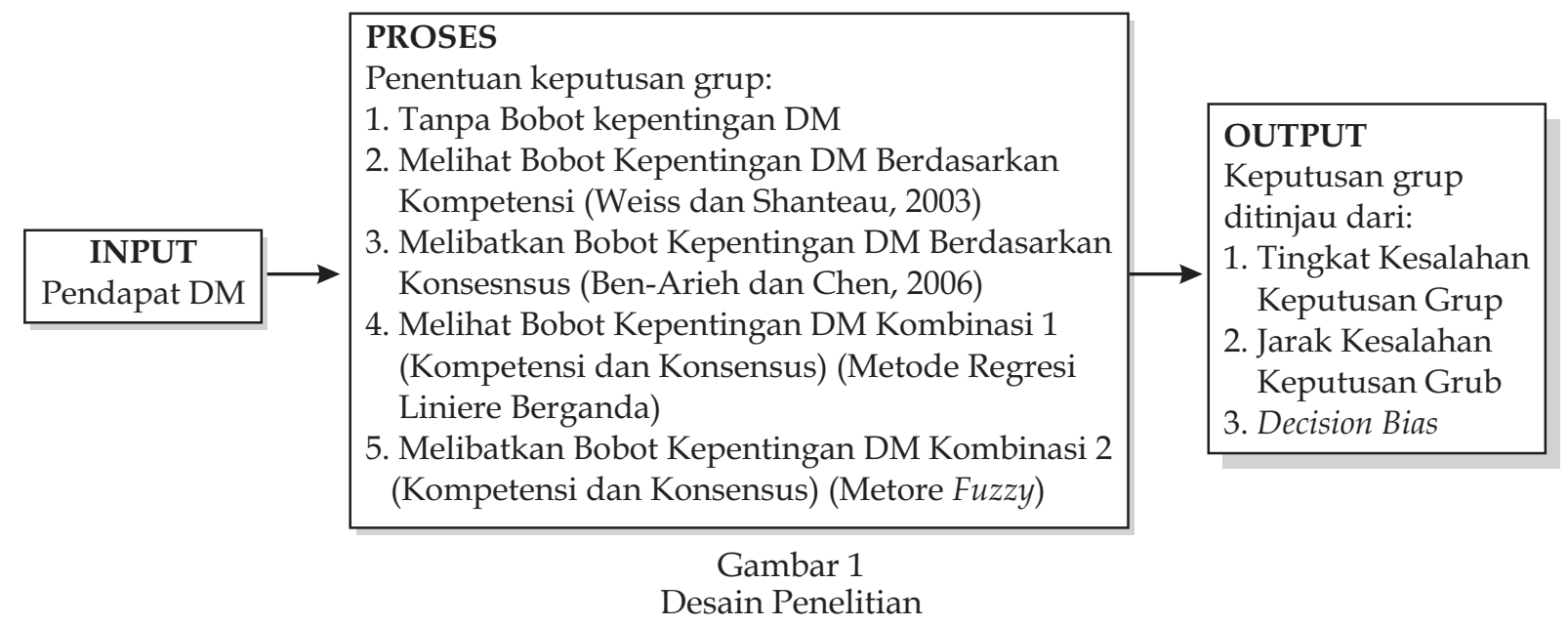

\section{Data Pendapat DM}

Berdasarkan hasil pengumpulan data yang telah dilakukan diperoleh data dengan rincian seperti ditampilkan pada tabel berikut: 
Tabel 1

Rekapitulasi Pendapat Individu dan PendapatExpert

\begin{tabular}{|c|c|c|c|c|c|c|c|c|c|c|c|}
\hline \multirow{3}{*}{ Alternatif ke - i } & \multicolumn{10}{|c|}{ Ranking Individu } & \multirow{3}{*}{ Expert Ranking } \\
\hline & \multicolumn{2}{|c|}{$\mathbf{P}_{1}$} & \multicolumn{2}{|c|}{$\mathbf{P}_{2}$} & \multicolumn{2}{|c|}{$\mathbf{P}_{3}$} & \multicolumn{2}{|c|}{$\mathbf{P}_{4}$} & \multicolumn{2}{|c|}{$\mathbf{P}_{5}$} & \\
\hline & $\mathbf{R}_{1}$ & $\mathbf{R}_{2}$ & $\mathbf{R}_{1}$ & $\mathbf{R}_{2}$ & $\mathbf{R}_{1}$ & $\mathbf{R}_{2}$ & $\mathbf{R}_{1}$ & $\mathbf{R}_{2}$ & $\mathbf{R}_{1}$ & $\mathbf{R}_{2}$ & \\
\hline 1 & 11 & 12 & 12 & 12 & 11 & 12 & 11 & 12 & 10 & 9 & 12 \\
\hline 2 & 1 & 1 & 1 & 1 & 1 & 1 & 1 & 1 & 1 & 1 & 1 \\
\hline 3 & 4 & 4 & 2 & 2 & 2 & 2 & 3 & 8 & 3 & 3 & 4 \\
\hline 4 & 5 & 10 & 7 & 6 & 5 & 6 & 5 & 2 & 4 & 12 & 11 \\
\hline 5 & 8 & 7 & 5 & 5 & 4 & 4 & 6 & 6 & 5 & 5 & 9 \\
\hline 6 & 7 & 9 & 6 & 7 & 6 & 5 & 2 & 7 & 6 & 6 & 5 \\
\hline 7 & 12 & 3 & 8 & 9 & 12 & 11 & 8 & 9 & 11 & 10 & 6 \\
\hline 8 & 2 & 2 & 3 & 4 & 3 & 7 & 7 & 11 & 7 & 4 & 3 \\
\hline 9 & 9 & 5 & 11 & 11 & 9 & 10 & 4 & 10 & 9 & 11 & 10 \\
\hline 10 & 3 & 8 & 4 & 3 & 10 & 3 & 9 & 3 & 2 & 2 & 2 \\
\hline 11 & 6 & 6 & 9 & 8 & 8 & 9 & 12 & 5 & 8 & 7 & 7 \\
\hline 12 & 10 & 11 & 10 & 10 & 7 & 8 & 10 & 4 & 12 & 8 & 8 \\
\hline
\end{tabular}

Tabel 1 merupakan pendapat dari masing-masing DM dalam suatu GDM dalam bentuk ranking. Data pada Tabel 1 tersebut akan diolah untuk mendapatkan bobot kepentingan DM dan keputusan grup.

\section{Penentuan Keputusan Grup Tanpa Mempertimbangkan Bobot DM}

Bobot kepentingan DM dalam perhitungan ini diabaikan atau tidak dilibatkan dalam penentuan keputusan grup. Pengolahan data pada Tabel 1 menggunakan Persamaan (1) dan Persamaan (2) (Alfares dan Duffuaa, 2008):

$$
W_{i, j}=100-\operatorname{Sn}(\text { rij-1) }
$$

dan

$$
\mathrm{Sn}=3,195+\underline{37,758}
$$

dengan:

$\mathrm{w}_{\mathrm{ij}}=$ Nilai bobot alternatif ke-i pada kasus ke-j

$\mathrm{Sn}=$ Nilai ketetapan

$\mathrm{r}_{\mathrm{ij}}=$ Rangking alternatif ke-i pada kasus ke-j

$\mathrm{n} \quad=$ Jumlah alternatif

Dari perhitungan menggunakan Persamaan (1) dan Persamaan (2) akan diperoleh hasil perhitungan tanpa melibatkan bobot kepentingan DM seperti pada Tabel 2.

Tabel 2

\begin{tabular}{|c|c|c|c|c|c|c|c|c|c|c|}
\hline \multirow{3}{*}{$\begin{array}{l}\text { Alternatif } \\
\text { ke - i }\end{array}$} & \multicolumn{10}{|c|}{ Bobot Alternatif } \\
\hline & \multicolumn{2}{|c|}{$\mathbf{P}_{1}$} & \multicolumn{2}{|c|}{$\mathbf{P}_{2}$} & \multicolumn{2}{|c|}{$\mathbf{P}_{2}$} & \multicolumn{2}{|c|}{$\overline{P_{4}}$} & \multicolumn{2}{|c|}{$\mathbf{P}_{\mathrm{s}}$} \\
\hline & $\mathbf{R}_{1}$ & $\mathbf{R}_{2}$ & $\mathbf{R}_{1}$ & $\mathbf{R}_{2}$ & $\mathbf{R}_{1}$ & $\mathbf{R}_{2}$ & $\mathbf{R}_{1}$ & $\mathbf{R}_{2}$ & $\mathbf{R}_{1}$ & $\mathbf{R}_{2}$ \\
\hline 1 & 36,585 & 30,244 & 30,244 & 30,244 & 36,585 & 30,244 & 36,585 & 30,244 & 42,927 & 49,268 \\
\hline 2 & 100,0 & 100,0 & 100,0 & 100,0 & 100,0 & 100,0 & 100,0 & 100,0 & 100,0 & 100,0 \\
\hline 3 & 80,976 & 80,976 & 93,659 & 93,659 & 93,659 & 93,659 & 87,317 & 55,610 & 87,317 & 87,317 \\
\hline 4 & 74,634 & 42,927 & 61,951 & 68,293 & 74,634 & 68,293 & 74,634 & 93,659 & 80,976 & 30,244 \\
\hline 5 & 55,610 & 61,951 & 74,634 & 74,634 & 80,976 & 80,976 & 68,293 & 68,293 & 74,634 & 74,634 \\
\hline 6 & 61,951 & 49,268 & 68,293 & 61,951 & 68,293 & 74,634 & 93,659 & 61,951 & 68,293 & 68,293 \\
\hline 7 & 30,244 & 87,317 & 55,610 & 49,268 & 30,244 & 36,585 & 55,610 & 49,268 & 36,585 & 42,927 \\
\hline 8 & 93,659 & 93,659 & 87,317 & 80,976 & 87,317 & 61,951 & 61,951 & 36,585 & 61,951 & 80,976 \\
\hline 9 & 49,268 & 74,634 & 36,585 & 36,585 & 49,268 & 42,927 & 80,976 & 42,927 & 49,268 & 36,585 \\
\hline 10 & 87,317 & 55,610 & 80,976 & 87,317 & 42,927 & 87,317 & 49,268 & 87,317 & 93,659 & 93,659 \\
\hline 11 & 68,293 & 68,293 & 49,268 & 55,610 & 55,610 & 49,268 & 30,244 & 74,634 & 55,610 & 61,951 \\
\hline 12 & 42,927 & 36,585 & 42,927 & 42,927 & 61,951 & 55,610 & 42,927 & 80,976 & 30,244 & 55,610 \\
\hline
\end{tabular}

Bobot Alternatif 
Tabel 2 merupakan bobot alternatif dari masing-masing DM berdasarkan data pada Tabel 1. Nilai 100 menunjukkan alternatif yang paling penting dibandingkan dengan alternatif yang lain. Semakin kecil bobot alternatif, semakin tidak penting alternatif tersebut menurut pendapat DM. Sedangkan semakin tinggi bobot alternatif, semakin penting alternatif tersebut menurut pendapat DM.

\section{Penentuan Bobot Kepentingan DM Berdasarkan Kompetensi}

Konsep dari penentuan bobot kepentingan DM berdasarkan kompetensi adalah semakin tinggi nilai kompetensi DM, maka akan semakin tinggi bobot kepentingan DM tersebut. Persamaan yang digunakan (Weiss dan Shantaeau, 2003):

$$
\begin{array}{ll}
\text { Diskriminasi }= & \frac{\sum_{j=1}^{n} \mathrm{r}^{\mathrm{r}\left(M_{j}-G M\right)^{2}}}{n-1} \\
\text { Inkonsistenasi }= & \frac{\sum_{j=1}^{n} \sum_{\left.i=1^{\mathrm{r}}\left(M_{i j}-M\right)\right)^{2}}^{n(r-1)}}{\text { Rasio CWS }=} \quad \frac{\text { Diskriminasi }}{\text { Inkonsistensi }}
\end{array}
$$

dengan:

$$
\begin{array}{lll}
\mathrm{r} & = & \text { Banyaknya replikasi } \\
\mathrm{M}_{\mathrm{j}} & = & \text { Rata-rata nilai individual } \\
& & \text { untuk kasus-j } \\
\mathrm{GM} & = & \text { Grand Mean dari nilai individual } \\
\mathrm{n} & = & \text { Banyaknya kasus yang berbeda } \\
\mathrm{M}_{\mathrm{ij}} & = & \text { Nilai individual untuk } \\
& & \text { replikasi-i pada kasus- } \mathrm{j} \\
\text { Rasio CWS }= & \text { Bobot kepentingan DM } \\
& & \text { berdasarkan kompetensi }
\end{array}
$$

Dari perhitungan menggunakan Persamaan (3), (4) dan (5), sehingga diperoleh hasil perhitungan seperti pada Tabel 3.

Tabel 3

Bobot Kepentingan DM Berdasarkan Kompetensi

\begin{tabular}{l|l|l}
\hline \multicolumn{1}{c|}{ DM } & \multicolumn{1}{|c|}{ Rasio CWS } & \multicolumn{1}{c}{ Bobot DM } \\
\hline$P_{1}$ & 2,961 & 0,02459 \\
\hline$P_{2}$ & 102,909 & 0,85451 \\
\hline$P_{3}$ & 7,576 & 0,06291 \\
\hline$P_{4}$ & 1,576 & 0,01308 \\
\hline$P_{5}$ & 5,409 & 0,04491 \\
\hline
\end{tabular}

Tabel 3 menunjukkan bobot kepetingan DM berdasarkan kompetensi masing-masing DM. Semakin tinggi bobot kepentingan DM berarti semakin tinggi kompetensi yang dimiliki oleh seorang DM. Berdasarkan hasil perhitungan pada Tabel 3, DM yang mempunyai bobot kepentingan tertinggi adalah $\mathrm{P}_{2}$. Hal ini menunjukkan bahwa $\mathrm{P}_{2}$ mempunyai kompetensi paling tinggi, jika dibandingkan dengan yang lain.

\section{Penentuan Bobot Kepentingan DM Berdasarkan Konsensus}

Konsep dasar yang digunakan dalam metode ini adalah semakin tinggi kontribusi DM terhadap keputusan grup, maka semakin tinggi bobot kepentingan DM tersebut. Persamaan yang digunakan (Ben-Arieh dan Chen, 2006):

$$
\begin{aligned}
& C_{i}=\sum_{k=1}^{q}\left[\left(1-\frac{\left|O_{A i}^{G}-O_{A i}^{E k}\right|}{n-1}\right)\right] \\
& C_{8}=\frac{1}{p} \sum_{i=1}^{p} C_{i} \\
& D_{i j}=\left|O^{G i}-O_{i j}^{p}\right| \\
& D_{m}=\sum_{j=1}^{m} D_{i j}
\end{aligned}
$$

dengan:

$C_{i} \quad=$ Level konsensus tiap alternatif $\mathrm{ke}-i$

$C_{G}=$ Level konsensus grup

$O_{A}^{G}=$ Alternatif konsensus

$\mathrm{O}^{E K}{ }_{A i}=$ Alternatif individu

$\mathrm{n} \quad=$ Jumlah alternatif

$\mathrm{p}=$ Jumlah alternatif

$D_{i j} \quad=$ Jarak opini grup atau expert dengan opini individu

$O_{i j}^{G}=$ Opini grup atau expert

$O_{i j}^{p}=$ Opini individu

$\mathrm{D}_{\mathrm{m}}$ = Jumlah jarak opini grup atau expert dengan opini individu

Dari perhitungan menggunakan Persamaan (6), (7), (8) dan (9), sehingga diperoleh hasil perhitungan berikut: 
Tabel 4

Bobot Kepentingan DM Berdasarkan Konsensus

\begin{tabular}{l|l|l}
\hline \multicolumn{1}{c|}{ DM } & \multicolumn{1}{c|}{ Nilai Konsensus } & \multicolumn{1}{c}{ Bobot DM } \\
\hline$P_{1}$ & 0,22909 & 0,19874 \\
\hline$P_{2}$ & 0,24364 & 0,21136 \\
\hline$P_{3}$ & 0,21182 & 0,18375 \\
\hline$P_{4}$ & 0,24727 & 0,21451 \\
\hline$P_{5}$ & 0,22091 & 0,19164 \\
\hline
\end{tabular}

Tabel 4 menunjukkan bobot kepetingan DM berdasarkan tingkat konsensus masingmasing DM. Semakin tinggi bobot kepentingan DM berarti semakin tinggi kontibusi yang dimiliki oleh seorang DM terhadap keputusan grup. Berdasarkan hasil perhitungan pada Tabel 4, DM yang mempunyai bobot kepentingan tertinggi adalah $\mathrm{P}_{4}$. Hal ini menunjukkan bahwa $\mathrm{P}_{4}$ mempunyai kontribusi terhadap grup paling tinggi, jika dibandingkan dengan yang lain.

\section{Penentuan Bobot Kepentingan DM Berdasarkan Model Kombinasi Pertama (Model Regresi)}

Berdasarkan model penentuan bobot kepentingan berdasarkan komptensi dan konsensus yang telah dijelaskan pada bagian sebelumnya, penelitian ini mencoba merencang model baru berdasarkan kompetensi dan konsensus untuk menentukan bobot kepentingan DM. Rancangan model kombinasi Pertama yang di usulkan dalam penelitian ini adalah model yang dirancang dengan menggunakan metode regresi.Penggunaan metode regresi dalam perancangan model kombinasi Pertama ini bertujuan untuk mendapatkan koefisien dari variabel kompetensi dan konsensus. Dengan mengetahui koefisien variabel kompetensi dan konsensus, peluang akan didapatkan bobot kepentingan DM yang sesuai lebih tinggi dibandingkan dengan hanya mempertimbangkan satu variabel saja. Persamaan yang digunakan adalah sebagai berikut:

$$
Y=b_{0}+b_{1} X_{1}=b_{2} X_{2}
$$

dengan:

$Y=$ Bobot Kepentingan DM Berdasarkan Kompetensi dan Konsensus

$\mathrm{b}_{0}=$ Konstanta

$\mathrm{b}_{1}=$ Konstanta Bobot Kepentingan DM Berdasarkan Kompetensi

$\mathrm{X}_{1}=$ Bobot Kepentingan DM Berdasarkan Kompetensi

$\mathrm{b}_{2}=$ Konstanta Bobot Kepentingan DM Berdasarkan Konsensus

Dari perhitungan menggunakan Persamaan (10) akan diperoleh hasil perhitungan seperti pada Tabel 5.

Tabel 5

Bobot Kepentingan DM Berdasarkan Model Kombinasi Pertama

\begin{tabular}{l|l}
\hline \multicolumn{1}{c|}{ DM } & \multicolumn{1}{|c}{ Bobot DM Kombinasi Pertama } \\
\hline$P_{1}$ & 0,18962 \\
\hline$P_{2}$ & 0,24225 \\
\hline$P_{3}$ & 0,18381 \\
\hline$P_{4}$ & 0,19734 \\
\hline$P_{5}$ & 0,18699 \\
\hline
\end{tabular}

Tabel 5 menunjukkan bobot kepetingan DM berdasarkan model kombinasi pertama (kombinasi kompetensi dan konsensus menggunakan metode regresi). Semakin tinggi bobot kepentingan DM berarti semakin tinggi kompetensi dan kontibusi yang dimiliki oleh seorang DM terhadap keputusan grup. Berdasarkan hasil perhitungan pada Tabel 5, DM yang mempunyai bobot kepentingan tertinggi adalah $\mathrm{P}_{2}$. Hal ini menunjukkan bahwa $\mathrm{P}_{2}$ mempunyai kompetensi dan kontribusi terhadap grup paling tinggi, jika dibandingkan dengan yang lain.

\section{Penentuan Bobot Kepentingan DM Berdasarkan Model Kombinasi Kedua (Model Fuzzy)}

Berdasarkan model penentuan bobot kepentingan berdasarkan komptensi dan konsensus yang telah dijelaskan pada bagian sebelumnya, penelitian ini mencoba merencang model baru berdasarkan kompetensi dan konsensus untuk 
menentukan bobot kepentingan DM. Rancangan model kombinasi kedua yang di usulkan dalam penelitian ini adalah model yang dirancang dengan menggunakan metode fuzzy. Penggunaan metode fuzzy dalam perancangan model kombinasi kedua ini bertujuan untuk mendapatkan nilai keanggotaan variabel kompetensi dan konsensus. Dengan mengetahui nilai keanggotaan variabel kompetensi dan konsensus dan dihitung menggunakan aturan tertentu, berpeluang akan didapatkan bobot kepentingan DM yang lebih sesuai, daripada hanya mempertimbangkan satu variabel saja. Persamaan yang digunakan dalam penentuan bobot kepentingan DM berdasarkan model kombinasi kedua sebagai berikut:

$$
\begin{aligned}
& \mu_{\text {Kmpt RENDAH }}[a]=\left\{\begin{array}{ll}
0 ; & a \leq 0 \text { atau } a \geq 0,5 \\
(a-0) /(0,25-0) ; & 0 \leq a<0,25 \\
(0,50-a) /(0,50-0,25) & 0,25 \leq a \leq 0,5
\end{array} 12\right. \\
& \mu_{\text {Kmpt SEDANG }}[a]=\left\{\begin{array}{ll}
0 ; & a \leq 0 \text { atau } a \geq 1 \\
(a-0) /(0,50-0) ; & 0 \leq a<0,50 \\
(1-a) /(1-0,50) & 0,50 \leq a \leq 1
\end{array} 13\right. \\
& \mu_{\text {Kmpt TINGGI }}[a]=\left\{\begin{array}{ll}
0 ; & a \leq 0,50 \text { atau } a \geq 1 \\
(a-0,50) /(0,75-0,50) ; & 0,50 \leq a<0,75 \\
(1-a) /(1-0,75) & 0,75 \leq a \leq 1
\end{array} 14\right. \\
& \mu_{\text {Kmpt RENDAH }}[b]= \begin{cases}0 ; & a \leq 0 \text { atau } b \geq 0,5 \\
(b-0) /(0,25-0) ; & 0 \leq a<0,25 \\
(0,50-b) /(0,50-0,25) & 0,25 \leq b \leq 0,5\end{cases} \\
& \mu_{\text {Kmpt SEDANG }}[b]=\left\{\begin{array}{ll}
0 ; & b \leq 0 \text { atau } b \geq 1 \\
(b-0) /(0,50-0) ; & 0 \leq b<0,50 \\
(1-b) /(1-0,50) & 0,50 \leq b \leq 1
\end{array} 16\right. \\
& \mu_{\text {Kmpp TINGGI }}[b]= \begin{cases}0 ; & b \leq 0,50 \text { atau } b \geq 1 \\
(b-0,50) /(0,75-0,50) ; & 0,50 \leq b<0,75 \\
(1-b) /(1-0,75) & 0,75 \leq b \leq 1\end{cases} \\
& \mu_{\text {Kmpt RENDAH }}[c]= \begin{cases}0 ; & c \leq 0 \text { atau } c \geq 0,5 \\
(c-0) /(0,25-0) ; & 0 \leq c<0,25 \\
(0,50-c) /(0,50-0,25) & 0,25 \leq c \leq 0,5\end{cases}
\end{aligned}
$$$$
\mu_{\text {Kmpt SEDANG }}[c]= \begin{cases}0 ; & c \leq 0 \text { atau } c \geq 1 \\ (c-0) /(0,50-0) ; & 0 \leq c<0,50 \\ (1-c) /(1-0,50) & 0,50 \leq c \leq 1\end{cases}
$$$$
\mu_{\text {Kmpt TINGGI }}[c]= \begin{cases}0 ; & c \leq 0,50 \text { atau } c \geq 1 \\ (c-0,50) /(0,75-0,50) ; & 0,50 \leq c<0,75 \\ (1-c) /(1-0,75) & 0,75 \leq c \leq 1\end{cases}
$$

Dari perhitungan menggunakan Persamaan (12) sampai dengan (20) akan diperoleh hasil perhitungan seperti pada Tabel 6.

Tabel 6

Bobot Kepentingan DM Berdasarkan Model Kombinasi Kedua

\begin{tabular}{l|l}
\hline \multicolumn{1}{c|}{ DM } & \multicolumn{1}{c}{ Bobot DM Kombinasi Kedua } \\
\hline$P_{1}$ & 0,06517 \\
\hline$P_{2}$ & 0,61434 \\
\hline$P_{3}$ & 0,16675 \\
\hline$P_{4}$ & 0,03468 \\
\hline$P_{5}$ & 0,11906 \\
\hline TOTAL & $\mathbf{1 , 0 0 0 0 0}$ \\
\hline
\end{tabular}

Tabel 6 menunjukkan bobot kepetingan DM berdasarkan model kombinasi dua (kombinasi kompetensi dan konsensus menggunakan metode fuzzy). Semakin tinggi bobot kepentingan DM berarti semakin tinggi kompetensi dan kontibusi yang dimiliki oleh seorang DM terhadap keputusan grup. Berdasarkan hasil perhitungan pada Tabel 6 DM yang mempunyai bobot kepentingan tertinggi adalah $\mathrm{P}_{2}$. Hal ini menunjukkan bahwa $\mathrm{P}_{2}$ mempunyai kompetensi dan kontribusi terhadap grup paling tinggi, jika dibandingkan dengan yang lain.

\section{Evaluasi Model Penentuan Bobot Kepentingan DM}

Pada penelitian ini telah dirancang dua model penentuan bobot kepentingan DM. Pertama adalah model penentuan bobot kepentingan DM yang didasarkan pada model kombinasi pertama. Kedua adalah model penentuan bobot kepentingan DM yang didasarkan pada model kombinasi dua. Kedua model yang telah dirancang ini memungkinkan masih terdapat kelemahan atau kekurang untuk itu pada bagian ini model yang telah dirancang akan dievaluasi. Persamaan yang digunakan untuk proses evaluasi model yang telah dirancang adalah dengan menggunakan Persamaan (21), dengan rincian sebagai berikut: 


$$
J K G=\sum_{i=1}^{n}\left|R A_{i}-E A_{i}\right|
$$

dengan:

$\mathrm{n} \quad=$ Jumlah Alternatif

JKG = Jarak ranking total keputusan grup dengan keputusan expert, kunci jawaban atau fakta
$\mathrm{RA}_{\mathrm{i}}=$ Ranking grup alternatif ke-i

$\mathrm{EA}_{\mathrm{i}}=$ Rankingexpert atau fakta alternatif ke-i

Berdasarkan tingkat kesalahan yang dihasilkan dari masing-masing metode penentuan bobot kepentingan DM yang telah dilibatkan dalam penentuan keputusan grup diperoleh hasil seperti Gambar 2.

\section{Tingkat Kesalahan Keputusan Grup}

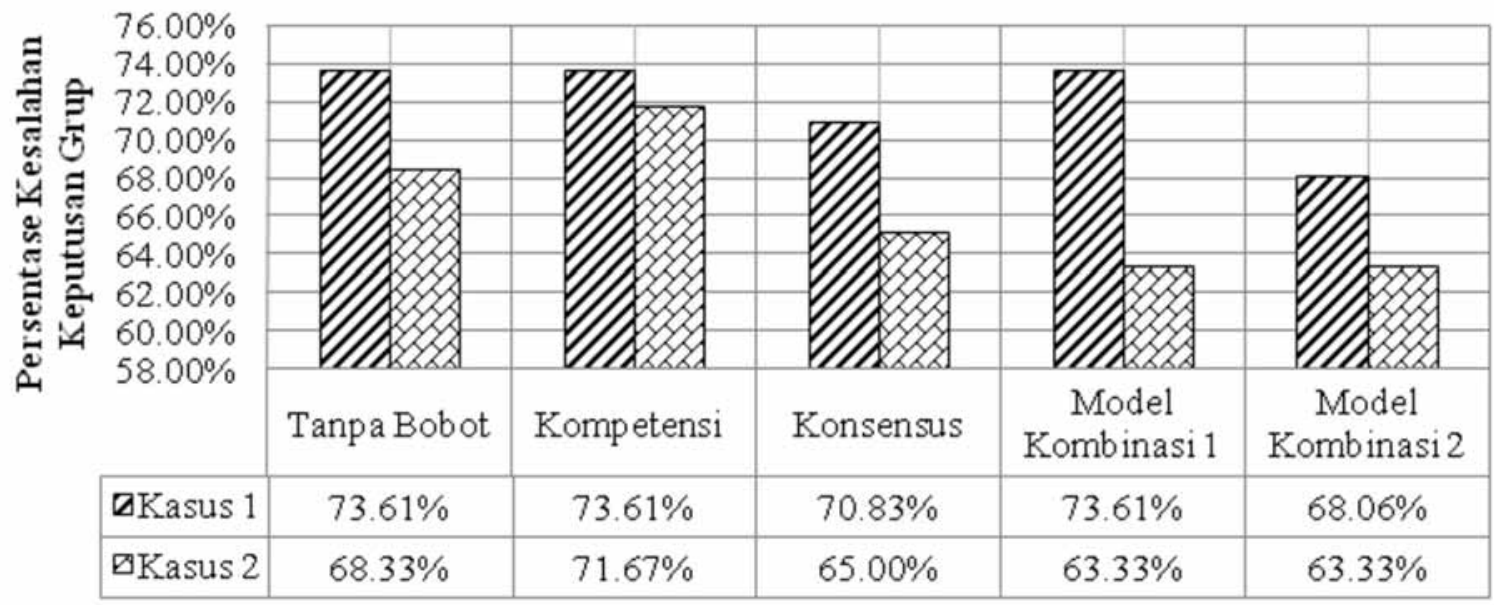

Gambar 2

Tingkat Kesalahan Keputusan Grup

Berdasarkan Gambar 2 rata-rata kesalahan keputusan grup yang dihasilkan melibatkan bobotkepentinganDMdarimodel kombinasi pertama dan model kombinasi kedua lebih rendah, jika dibandingkan dengan tingkat kesalahan keputusan grup yang dihasilkan tanpa menggunakan bobot kepentingan DM dan yang melibatkan bobot kepentingan DM dari model kompetensi dan model konsensus. Hal ini dapat terjadi karena model kombinasi pertama dan model kombinasi kedua yang dirancang melibatkan variabel kompetensi dan konsensus dalam proses penentuaan bobot kepentingan DM sehingga memungkinkan diperoleh bobot kepentingan DM yang lebih sesuai. Secara tidak langsung dengan melibatkan bobot kepentingan DM dalam suatu keputusan grup dapat mempengaruhi hasil keputusan grup. Keterlibatan variabel kompetensi dan konsensus dalam penentuan bobot kepentingan DM memberikan hasil keputusan grup yang berbeda. Model kombinasi pertama dan model kombinasi kedua yang dirancang dalam penelitian ini lebih kepada meningkatkan keunggulan model penentuan bobot kepentingan DM berdasarkan kompetensi dan konsensus. Tidak dapat dipungkiri bahwa model penentuan bobot kepentingan DM berdasarkan kompetensi dan konsensus adalah model yang handal ditinjau dari penentuan bobot kepentingan DM, tetapi model tersebut di kasus atau grup yang digunakan dalam penelitian ini mengalami kesalahan lebih dari 75\%. Model kombinasi pertama dan model kombinasi kedua yang dirancang dalam penelitian ini berusaha untuk lebih meningkatkan keunggulan dari model penentuan bobot kepentingan DM berdasarkan kompetensi dan konsensus.

Pada penelitian ini juga dilakukan analisis terkait decision bias. Decision bias yang dimaksud pada penelitian ini adalah di mana 
keputusan grup didominasi oleh satu orang decision maker, padahal decision maker tersebut memiliki jawaban alternatif yang belum tentu benar. Semakin kecil nilai kesalahan pemberian bobot kepentingan DM, maka semakin kecil decision bias yang terjadi dalam suatu GDM. Adanya decision bias dalam suatu GDM berakibat kepada meningkatnya kesalahan keputusan yang dihasilkan dari suatu GDM. Decision bias dapat terjadi apabila proses konsensus dilakukan untuk menghasilkan satu keputusan bersama terhadap alternatif solusi permasalahan yang
ada.Decision bias adalah di mana keputusan grup didominasi oleh satu DM sehingga DM lain mengikuti, padahal keputusan yang diambil belum tentu keputusan yang benar, maka perhitungan menggunakan model kompetensi, model konsensus, model kombinasi pertama dan model kombinasi kedua menjadi salah satu solusi untuk mencari alternatif terbaik dan mengurangi terjadinya decision bias dalam suatu GDM. Hasil perhitungan yang lebih rinci dan detail dari kasus yang digunakan dari masingmasing grup disajikan sebagai berikut:

Tabel 7

Perhitungan Deviasi Grup dan Penentuan Bias atau Tidak Bias

\begin{tabular}{c|l|c|c|c|c|c|c}
\hline \multicolumn{1}{c|}{ Metode } & \multicolumn{1}{c|}{ Deviasi } & P1 & P2 & P3 & P4 & P5 & Keterangan \\
\hline \multirow{2}{*}{ Kompetensi } & Keputusan Grup & 23 & $\mathbf{3}$ & 16 & 27 & 14 & Tidak Bias \\
\cline { 2 - 9 } & Ranking Expert & 23 & $\mathbf{1 9}$ & 28 & 35 & 24 & \\
\hline \multirow{2}{*}{ Konsensus } & Keputusan Grup & 23 & $\mathbf{7}$ & 14 & 27 & 12 & \multirow{2}{*}{ Tidak Bias } \\
\cline { 2 - 9 } & Ranking Expert & 23 & $\mathbf{1 9}$ & 28 & 35 & 24 & \\
\hline \multirow{2}{*}{ Kombinasi 1 } & Keputusan Grup & 23 & $\mathbf{7}$ & 14 & 27 & 12 & \multirow{2}{*}{ Tidak Bias } \\
\cline { 2 - 8 } & Ranking Expert & 23 & $\mathbf{1 9}$ & 28 & 35 & 24 & \\
\cline { 2 - 8 } & Keputusan Grup & 23 & $\mathbf{7}$ & 14 & 27 & 12 & \multirow{2}{*}{ Tidak Bias } \\
\cline { 2 - 7 } & Ranking Expert & 23 & $\mathbf{1 9}$ & 28 & 35 & 24 & \\
\hline
\end{tabular}

Hasil perhitungan dikatakan bias ketika penentuan bobot kepentingan DM dengan data keputusan grup tidak sesuai dengan pendapat expert. Sedangkan dikatakan tidak bias adalah ketika penentuan bobot kepentingan DM dengan data keputusan grup sesuai dengan pendapat expert. Dari Tabel 7 dapat diketahui bahwa dengan menggunakan metode kompetensi, metode konsensus, metode kombinasi pertama atau metode kombinasi kedua dalam melakukan penentuan bobot kepentingan DM dalam suatu GDM dapat menghindari terjadinya decision bias dalam GDM tersebut. Tidak terjadinya decision bias disebabkan keputusan grup pada awalnya tidak terjadi dicision bias sehingga dengan demikian dapat disimpulkan bahwa jika pada keputusan grup awal tidak terjadi decision bias, maka menggunakan metode penentuan bobot kepentingan DM berdasarkan kompetensi, konsensus, kombinasi pertama maupun kombinasi kedua akan menghasilkan bobot kepentingan DM yang dapat menghindarkan dari decision bias.

\section{SIMPULAN}

Penentuan bobot kepentingan DM berdasarkan evaluasi penilaian DM terhadap alternatif dengan memperhatikan kompetensi dan konsensus dapat dilakukan dengan perancangan model berdasarkan metode regresi dan metode fuzzy. Dengan menggunakan metode tersebut diperoleh model regresi dan model fuzzy untuk penentuan bobot kepentingan DM memperhatikan kompetensi dan konsensus.

Penggunaan model kombinasi pertama atau model kombinasi kedua dalam suatu GDM untuk penentuan bobot kepentingan DM dapat mengurangi kesalahan keputusan grup yang terjadi dalam suatu GDM pada kasus dan data yang digunakan dalam penelitian ini. Model kombinasi 1 (Model 
Regresi) atau model kombinasi 2 (Model Fuzzy) dapat menghindakan terjadinya decision bias, ketika hasil perhitungan salah satu metode berdasarkan kompetensi atau konsensus tidak terjadi decision bias. Semakin baik akurasi yang dihasilkan model penentuan bobot kepentingan DM, maka semakin komplek proses perhitungan yang perlu dilakukan.

Berdasarkan hasil penelitian yang telah dilakukan, saran yang dapat dipertimbangkan yaitu pada penelitian ini data yang digunakan dalam berupa skala ordinal. Diharapkan penelitian selanjutnya dapat dengan menggunakan skala penilaian yang lain. Selain itu, diharapkan pada penelitian selanjutnya melakukan penambahan replikasi untuk mendapatkan informasi dari DM yang lebih lengkap.

\section{DAFTAR PUSTAKA}

Alfares,H.,danDuffuaa, O.,2008, Determining Aggregate Criteria Weights from Criteria Rankings by a Group of Decision Makers. International Journal of Information Technology \& Decision Making, 7(4), 1-13.

Alonso, S., Herrera-Viedma, E., Chiclana, F., dan Herrera, F., 2010, A Web Based Consensus Support Systems for Group Decision Making Problems and Incomplete Preferences, Information Sciences, 180(23), 4477-4495.

Ben-Arieh, D., dan Chen, Z., 2006, Linguistic-Labels Aggregation and Consensus Measure for Autocratic Decision Making Using Group Recommendations, IEEE Transactions on system, man and cybernetics, 36(3), 558-568.

Ekel, P., Queiroz, J., Parreiras, R., dan Palhares, R., 2009, Fuzzy Set Based Model and Method of Multicriteria Group Decision Making, Nonlinear Analysis, 71(12), 409-419.

Herrera, F., Herrera-Viedma, E., dan Verdegay, J.L., 1997, Linguistic
Measures Based on Fuzzy Coincidence for Reaching Consensus in Group Decision Making, International Journal of Approximate Reasoning, 16(3-4), 309-334.

Kacprzyk., Fedrizzi, M., dan Nurmi, H., 1992, Group Decision Making and Consensus under Fuzzy Preferences and Fuzzy Majority, Fuzzy Sets and System, 49(1), 21-31.

Kim, S.H., dan Ahn, B.S., 1997, Group Decision Making Procedure Considering Preference Strength under Incomplete Information, Computers Ops Res, 24(12), 1101-1112.

Ness, J., dan Hoffman, C., 1998, Putting Sense into Consensus: Solving the Puzzle of Making Team Decision,VISTA Associates.

P'Erez, I.J., Alonso, S., Cabrerizo, F.J., Lu, J., dan Herrera-Viedma, E., 2011, ModellingHeterogeneity among Experts in Multi-kriteria Group Decision Making Problems, Lecture Note in Computer Science, 6820(2011), 55-66.

Parreiras, R.O., Ekel, P.Y., Martini, J.S.C., dan Palhares, R.M., 2010, A Flexible Consensus Scheme for Multi Criteria Group Decision Making under Linguistic Assessment, Information Sciences, 180(7), 1075-1089.

Weiss, D.J., dan Shanteau, J., 2003, Empirical Assessment of Expertise, Human Factor, 45(1), 104-116.

Yue, Z.L., 2011, Deriving Decision Maker's Weights Based on Distance Measure for Interval-Valued Intuitionistic Fuzzy Group Decision Making, Expert Systems with Applications, 38(9), 11665-11670.

Yue, Z.L., 2012, Approach to Group Decision Making Based on Determining Weights of Experts by Using Projection Method, Applied Mathematical Modeling, 36(7), 29002910. 